\title{
Research on the Integration of China's Tourism Industry and Financial Industry under the Background of "the Belt and Road"
}

\author{
Su Weiling ${ }^{1, \mathrm{a}}$, Ren Tongtong ${ }^{2, \mathrm{~b}}$ \\ ${ }^{1}$ School of Tourism Dalian University Dalian, China \\ ${ }^{2}$ School of Economics and Management Dalian University Dalian, China,
}

\begin{abstract}
Under the background of "the Belt and Road", the rapid development of tourism and financial industry in China has made important contributions to the economic and cultural construction of "the Belt and Road ". Through the construction of coupling correlation model and coupling index system, this paper conducts an empirical analysis on the integrated development of tourism and financial industry in China from 2013 to 2017 under the background of "the Belt and Road". The results show that China's tourism and financial industry have developed rapidly in the period of 2013-2017, and there is a significant coupling relationship between them. However, there is a lag in the development of financial industry in 2013-2014 and a lag in the development of tourism industry in 2015-2017. In general, under the background of "the Belt and Road", China's tourism and financial industry continue to develop, and the links and interactions between the two industries are getting stronger and stronger. The two industries promote each other, and finally achieve the high-quality coordinated development of tourism and financial industry.
\end{abstract}

\section{Introduction}

In 2013, Chinese President Xi Jinping first proposed "the Belt and Road" national initiative, in which "the Belt" refers to "the Silk Road Economic Belt"; "The Road" refers to "the 21st-Century Maritime Silk Road"[1]. The proposal of this initiative plays a vital role in the development of China's tourism industry. In 2015, the National Tourism Administration set the theme of tourism as "the Silk Road Tourism Year", which is enough to show the importance of "the Belt and Road" initiative for tourism development [2]. As the most important part of the economy, finance needs to be applied to the real economy. Similarly, tourism development also needs financial support and services.

Research on the coordinated development of tourism and finance by foreign scholars is mainly reflected in the support of the financial industry for the development of tourism. Thomas Bieger (2001) mainly explained the principle of investment in tourism enterprises and international tourism [3]. Vogel (2003) made an empirical analysis of hotels, theme parks and airlines in the tourism industry from the aspects of financing, production and operation, and economic characteristics[4]. Hawkins and Mann (2007) analysed the World Bank's aspiration to achieve the UN millennium development goals in the tourism industry [5]. Markandya (2014) analysed the World Bank's investment in tourism projects, and came to the following conclusions: sustainable use of national tourism resources has a potential contribution to economic growth, so that more investment in tourism industry can achieve greater profits [6].

Compared with foreign research scholars, domestic scholars in China have a slightly late study on tourism and finance. Zhu xia (2013) put forward suggestions on accelerating the integrated development of tourism and finance to achieve a win-win situation[7]. Gong yan (2015) analysed the factors affecting the integrated development of tourism and the financial industry, constructed the model of the integrated development of tourism and the financial industry, and proposed the path of their integrated development, further promoting the coordinated development of the integrated development of the financial industry and the tourism industry [8]. Hua ping (2015) analysed the correlation between the integration of tourism and financial industry in Henan province from 2006 to 2013 by using the grey relational degree model, and put forward relevant countermeasures and suggestions [9]. Gong yan and Guo zhengrong (2017) made an empirical analysis of the coupling development of tourism and financial industry in Jiangsu province by using the coupling evaluation model, and learned that tourism and financial industry in Jiangsu province showed a significant coupling development relationship [10]. Shao yuzhen (2018) analysed the integration degree of tourism and financial industry in Zhejiang province from 2001 to 2016 through the grey relational model, and concluded that the integration level of Zhejiang province was on the rise [11]. Qin zhaoxiang and Zhang wei (2018) analysed the factors affecting the coupling development of tourism and financial industry, and proposed measures such as strengthening tourism credit reconstruction, improving banking financial support, and innovating tourism

asuweiling@dlu.edu.cn; b18332703396@163.com 
insurance system [12]. Shao yuzhen (2018) drew the conclusion that the integration discussion and evaluation of tourism and financial industry were weak through grey correlation analysis [13]. Zhang wenjing (2018) calculated the financial industry and tourism industry of Henan province from 2007 to 2016 through the method of grey correlation degree, and proposed suggestions for the future integrated development of the tourism and financial industry of Henan province [14]. Shi xin (2018) analysed the impact of each tourism index on the added value of the financial industry by using the grey correlation method, and proposed suggestions [15].

Based on the above research results, foreign scholars believe that the financial industry plays a great role in promoting the development of tourism, but there are few studies on the integration of the two. Most domestic scholars focus on the integration of tourism and financial industry in a particular province in China, which is more flexible and broad in research methods and contents. Since "the Belt and Road" initiative was put forward and implemented in 2013, China's tourism and financial industry have been developing rapidly, and their integration has been increasingly enhanced. In this paper, the coupling correlation model is used to quantitatively study the degree of integration between tourism and financial industry in China under the background of " the Belt and Road".

\section{Model and index construction of the coupling and coordinated development of tourism and financial industry in China}

\subsection{Coupling correlation model}

\subsubsection{The development of comprehensive contribution function}

Let the variable $X_{i j}(i=1 ; j=1,2 \ldots n)$ is the $j_{\text {th }}$ indicator in system $i$ (i.e. tourism system), variable $X_{i k}(i=2 ; k=1,2 \ldots$ $\mathrm{m})$ is the $k_{\mathrm{th}}$ indicator in system $\mathrm{i}$ (i.e. financial system). Among them, $A_{i j}$ and $B_{i j}$ are the maximum and minimum values of $\mathrm{X}_{\mathrm{ij}}$. $\mathrm{A}_{\mathrm{ik}}$ and $\mathrm{B}_{\mathrm{ik}}$ are the maximum and minimum values of $\mathrm{X}_{\mathrm{ik}}$.

Before the establishment of coupling degree model, it is necessary to find out the indicators of tourism industry and financial industry, and carry out the non-quantitative treatment of the indicators. Since the indicators selected by the paper are positive indicators, that is, the index attributes are positive and the index data is greater than zero, the normalized processing of the data is performed using the forward index method ${ }^{[16]}$. The calculation formula is as follows:

$$
\begin{aligned}
\mathrm{X}_{\mathrm{ij}}=\left(\Xi_{\iota \varphi}-\mathrm{B}_{\iota \varphi}\right) /\left(\mathrm{A}_{\iota \varphi}-\mathrm{B}_{\iota \varphi}\right) \\
\mathrm{X}_{\mathrm{ik}}=\left(\Xi_{\iota \kappa}-\mathrm{B}_{\iota \kappa}\right) /\left(\mathrm{A}_{\iota \kappa}-\mathrm{B}_{\iota \kappa}\right)
\end{aligned}
$$

Since the value of particular index is 0 after the nonquantization treatment, in order to make the logarithm meaningful when calculating the weight, the value without quantization treatment is translated by 0.001 units according to the practice of Shu xiaolin ${ }^{[17]}(2015)$. The calculation formula is as follows:

$$
\begin{gathered}
\mathrm{x}_{\mathrm{ij}}=\left(\Xi_{\imath \varphi}-\mathrm{B}_{\imath \varphi}\right) /(\mathrm{A} \imath \varphi-\mathrm{B} \imath \varphi)+0.001 \\
\mathrm{X}_{\mathrm{ik}}=(\Xi \iota \kappa-\mathrm{B} \imath \kappa) /(\mathrm{A} \imath \kappa-\mathrm{B} \imath \kappa)+0.001
\end{gathered}
$$

Each system of tourism and financial industry has many subsystems, and each subsystem contributes to its own system, so the comprehensive contribution degree of each system is:

$$
\begin{aligned}
\mathrm{Y}_{1} & =\sum_{\mathrm{j}=1}^{\mathrm{n}} \lambda_{\mathrm{ij}} \mathrm{x}_{\mathrm{ij}} \quad \mathrm{Y}_{2}=\sum_{\mathrm{k}=1}^{\mathrm{m}} \lambda_{\mathrm{ik}} \mathrm{x}_{\mathrm{ik}} \\
\sum_{\mathrm{j}=1}^{\mathrm{n}} \lambda_{\mathrm{ij}} & =1 \quad \sum_{\mathrm{k}=1}^{\mathrm{m}} \lambda_{\mathrm{ik}}=1
\end{aligned}
$$

$\mathrm{U}_{1}$ is the comprehensive contribution to the development of the tourism system, $\mathrm{U}_{2}$ is the comprehensive contribution to the development of the financial system. $\lambda_{\mathrm{ij}}$ and $\lambda_{\mathrm{ik}}$ are the weights corresponding to the order parameters. The weights are determined by the entropy method, and the calculation steps and formulas are as follows:

a) alculate the proportion of the index value in the $i^{\text {th }}$ year of item $j(k)$ :

$$
\mathrm{P}_{\mathrm{ij}}=\frac{\mathrm{x}_{\mathrm{ij}}}{\sum_{\mathrm{i}=1}^{2} \mathrm{x}_{\mathrm{ij}}} \quad \mathrm{P}_{\mathrm{ik}}=\frac{\mathrm{x}_{\mathrm{ik}}}{\sum_{\mathrm{i}=1}^{2} \mathrm{x}_{\mathrm{ik}}}
$$

b) Calculate the entropy value of indexes $j$ and $k$ :

$$
\sum_{\mathrm{i}=1}^{2} \mathrm{P}_{\mathrm{ij}} \ln \mathrm{P}_{\mathrm{ij}} \quad \sum_{\mathrm{i}=1}^{2} \mathrm{P}_{\mathrm{ik}} \ln \mathrm{P}_{\mathrm{ik}}
$$

c) Calculate the information redundancy of indicators $j$ and $k$ :

$$
\mathrm{H} \varphi=1-\mathrm{E} \varphi \quad \mathrm{H} \kappa=1-\mathrm{E} \kappa
$$

d) Calculate the weight of indicators $j$ and $k$ :

$$
\Omega_{\varphi}=\frac{\mathrm{H}_{\mathrm{j}}}{\sum_{\mathrm{j}=1}^{\mathrm{n}} \mathrm{H}_{\mathrm{j}}} \quad \Omega_{\mathrm{K}}=\frac{\mathrm{H}_{\mathrm{k}}}{\sum_{\mathrm{j}=1}^{\mathrm{k}} \mathrm{H}_{\mathrm{k}}}
$$

\subsection{Coupling degree function}

The coupling degree is determined by using the concept of capacity coupling in physics and the model of capacity coupling system ${ }^{[18]}$. Let $\mathrm{C}$ be the coupling degree of tourism and financial system, then the coupling degree function is:

$$
\mathrm{C}=2 \sqrt{\left(\mathrm{U}_{1} * \mathrm{U}_{2}\right) /\left(\mathrm{U}_{1}+\mathrm{U}_{2}\right)^{2}}
$$

Among them, $C \in[0,1)$,the higher the value of $C$, the higher the coupling correlation between tourism and finance industries, but it will not reach the ideal value of 1 .

\subsection{Coupling coordination degree model}

Coordination is an important concept in the view of system science and the theory of coordination, which refers to a virtuous cycle of mutual cooperation, cooperation and promotion among subsystems or elements in order to achieve the overall evolution goal of the system ${ }^{[19]}$. Therefore, a coupling coordination degree 
model is established to evaluate the two systems of tourism and financial industry. The model is as follows:

$$
\mathrm{D}=\sqrt{\mathrm{C} * \mathrm{~T}} \quad \mathrm{~T}=\alpha \mathrm{U}_{1}+\beta \mathrm{U}_{2}
$$

Among them, D represents the coupling coordination degree of the two systems of tourism and financial industry; T represents the comprehensive evaluation index of the two systems of tourism and financial industry, with values between 0 and $1 ; \alpha$ and $\beta$ respectively represent the contribution coefficient of tourism and financial industry to the coupling system, and $\alpha+\beta=1$. Through interviews with experts and industry insiders, it is found that since tourism and financial industry are both service industries, the degree of interaction between the two industries is basically the same, and they are of equal importance to economic development, so $\alpha=\beta=0.5^{[20]}$ is selected. Coupling coordination degree $\mathrm{D}$ is to measure the degree and level of coordinated development between tourism and financial industry. Referring to Liao zhongbin's research results ${ }^{[21]}$, the interval and level of coupling coordination degree are divided, as shown in table 1 .

Table1. The classification criteria of coupled coordination degree

\begin{tabular}{|c|c|c|}
\hline $\begin{array}{c}\text { Serial } \\
\text { number }\end{array}$ & $\begin{array}{c}\text { Coordination degree } \\
\text { interval }\end{array}$ & Coordination level \\
\hline 1 & $0-0.09$ & Extreme imbalance \\
\hline 2 & $0.10-0.19$ & Serious imbalance \\
\hline 3 & $0.20-0.29$ & Moderate imbalance \\
\hline 4 & $0.30-0.39$ & Mild imbalance \\
\hline 5 & $0.40-0.49$ & On the verge of imbalance \\
\hline 6 & $0.50-0.59$ & Barely coordination \\
\hline 7 & $0.60-0.69$ & Primary coordination \\
\hline 8 & $0.70-0.79$ & Middle pole coordination \\
\hline 9 & $0.80-0.89$ & Good coordination \\
\hline 10 & $0.90-1.00$ & Quality coordination \\
\hline
\end{tabular}

Data source: Liao Chongbin. Quantitative judgment and classification system for coordinated development of environment and economy: A case study of the city group in the Pearl River Delta[J]. Tropical Geography,1999,19(2): 171-177.

\section{Data analysis}

\subsection{Data sources}

The data of the thesis comes from the national tourism and financial industry data. In order to guarantee the scientific nature and authenticity of the empirical results of this paper, the original data of this paper are all from various authorities, including the 2014-2018 "China tourism statistics yearbook", 2014-2018"Chinese financial statistical yearbook", 2014-2018 "China statistical yearbook", and so on.

\subsection{Indicator weight determination}

Tourism system chose 15 measurement indexs, respectively, number of inbound tourism, number of domestic tourism, international tourism revenue, domestic tourism income, total tourism revenue, number of travel agencies, A-level tourist attractions, number of Malaysian tourists in China, number of Philippine tourists in China, number of Singapore tourists in China, number of Thai tourists in China, number of Indian tourists in China, number of Israeli tourists in China, number of polish tourists in China, number of Egyptian tourists in China. Among them, Malaysia, the Philippines, Singapore, Thailand, India, Israel, Poland and Egypt are all tourist generating countries of China along "the Belt and Road" route. The financial system consists mainly of banking, insurance and securities. In order to better study the coupling coordination degree between financial industry and tourism, this paper selects 8 financial measurement indexes, which are respectively balance of deposits of financial institutions, balance of loans from financial institutions, number of securities listed companies, total market value of securities and stocks, premium income, premium density, premium depth and number of insurance companies.

In the calculation of the weights of the national tourism and financial industry, the processing of the positive indicators of the above data and the calculation steps of entropy value weighting method, namely formula (1) - (7), are followed. Then, excel software is used to calculate the weights of the indexes of the two industries. The results of the weights of each system are shown in table2.

Table2. The index and weight of tourism industry system and financial industry system

\begin{tabular}{|c|c|c|c|}
\hline System & Evaluation indexes & Unit & Weight \\
\hline \multirow{15}{*}{$\begin{array}{l}\text { Tourism } \\
\text { industry } \\
\text { system }\end{array}$} & Number of inbound tourists & $\begin{array}{c}\text { Thousands of } \\
\text { People }\end{array}$ & 0.0852 \\
\hline & Number of domestic tourists & $\begin{array}{l}\text { Million } \\
\text { People }\end{array}$ & 0.0655 \\
\hline & International Tourism Income & $\begin{array}{c}\text { Billions of } \\
\text { Dollars }\end{array}$ & 0.0413 \\
\hline & Domestic tourism revenue & Billion & 0.0652 \\
\hline & Total Tourism Income & Trillion & 0.0553 \\
\hline & Number of travel agencies & Piece & 0.0702 \\
\hline & A-level tourist attraction & Piece & 0.0643 \\
\hline & $\begin{array}{l}\text { Number of Malaysian tourists } \\
\text { in China }\end{array}$ & $\begin{array}{c}\text { Thousands of } \\
\text { People }\end{array}$ & 0.0528 \\
\hline & $\begin{array}{l}\text { Number of Philippine tourists } \\
\text { in China }\end{array}$ & $\begin{array}{l}\text { Thousands of } \\
\text { People }\end{array}$ & 0.0898 \\
\hline & $\begin{array}{l}\text { Number of Singapore tourists } \\
\text { in China }\end{array}$ & $\begin{array}{l}\text { Thousands of } \\
\text { People }\end{array}$ & 0.0573 \\
\hline & $\begin{array}{c}\text { Number of Thai tourists in } \\
\text { China }\end{array}$ & $\begin{array}{l}\text { Thousands of } \\
\text { People }\end{array}$ & 0.0808 \\
\hline & $\begin{array}{c}\text { Number of Indian tourists in } \\
\text { China }\end{array}$ & $\begin{array}{l}\text { Thousands of } \\
\text { People }\end{array}$ & 0.0665 \\
\hline & $\begin{array}{l}\text { Number of Israeli tourists in } \\
\text { China }\end{array}$ & $\begin{array}{l}\text { Thousands of } \\
\text { People }\end{array}$ & 0.0847 \\
\hline & $\begin{array}{c}\text { Number of polish tourists in } \\
\text { China }\end{array}$ & $\begin{array}{l}\text { Thousands of } \\
\text { People }\end{array}$ & 0.0792 \\
\hline & $\begin{array}{l}\text { Number of Egyptian tourists to } \\
\text { China }\end{array}$ & $\begin{array}{l}\text { Thousands of } \\
\text { People }\end{array}$ & 0.0419 \\
\hline \multirow{3}{*}{$\begin{array}{l}\text { Financial } \\
\text { industry } \\
\text { system }\end{array}$} & $\begin{array}{l}\text { Balance of deposits of } \\
\text { financial institutions }\end{array}$ & Billion & 0.1205 \\
\hline & $\begin{array}{l}\text { Balance of loans from } \\
\text { financial institutions }\end{array}$ & Billion & 0.1154 \\
\hline & $\begin{array}{c}\text { Number of Listed Securities } \\
\text { Companies }\end{array}$ & Piece & 0.1419 \\
\hline
\end{tabular}




\begin{tabular}{|c|c|c|c|}
\hline \multirow{4}{*}{} & $\begin{array}{c}\text { Total Market Value of } \\
\text { Securities and Stocks }\end{array}$ & Billion & 0.0881 \\
\cline { 2 - 4 } & Premium income & Billion & 0.1318 \\
\cline { 2 - 4 } & Insurance density & Yuan/Person & 0.1260 \\
\cline { 2 - 4 } & Insurance penetration & Percent & 0.1414 \\
\cline { 2 - 4 } & $\begin{array}{c}\text { Number of insurance } \\
\text { companies }\end{array}$ & Piece & 0.1349 \\
\hline
\end{tabular}

\subsection{Determination of coupling degree value and coupling compatibility degree value}

According to the above coupling correlation model formula (8) - (9), the comprehensive contribution degree of the two systems of tourism and financial industry in China from 2013 to 2017 is respectively calculated. The coupling degree value and coupling coordination degree value between the two systems are shown in table3.

Table3. Coupling and Coordination Degree and Evaluation of China's Tourism Industry and Financial Industry under the Background of "the Belt and Road" in 2013-2017

\begin{tabular}{|c|c|c|c|c|c|c|c|}
\hline $\begin{array}{c}\mathbf{Y e} \\
\mathbf{a r}\end{array}$ & $\mathbf{U}_{\mathbf{1}}$ & $\mathbf{U}_{\mathbf{2}}$ & $\begin{array}{c}\mathbf{U}_{\mathbf{1}} \mathbf{\text { vs}} \\
\mathbf{U}_{\mathbf{2}}\end{array}$ & $\mathbf{T}$ & $\mathbf{C}$ & $\mathbf{D}$ & $\begin{array}{c}\text { Coordinati } \\
\text { onlevel }\end{array}$ \\
\hline 20 & 0.15 & 0.00 & $\begin{array}{c}\text { Finan } \\
\text { cial } \\
\text { lag }\end{array}$ & $\begin{array}{c}0.07 \\
75\end{array}$ & $\begin{array}{c}0.16 \\
02\end{array}$ & $\begin{array}{c}0.11 \\
14\end{array}$ & $\begin{array}{c}\text { Serious } \\
\text { imbalance }\end{array}$ \\
\hline 20 & $\begin{array}{c}0.25 \\
43\end{array}$ & $\begin{array}{c}0.17 \\
44\end{array}$ & $\begin{array}{c}\text { Finan } \\
\text { cial } \\
\text { lag }\end{array}$ & $\begin{array}{c}0.21 \\
44\end{array}$ & $\begin{array}{c}0.98 \\
25\end{array}$ & $\begin{array}{c}0.45 \\
89\end{array}$ & $\begin{array}{c}\text { On the } \\
\text { verge of } \\
\text { imbalance }\end{array}$ \\
\hline 20 & 0.33 & 0.45 & $\begin{array}{c}\text { Touri } \\
\text { sm } \\
15\end{array}$ & 0.39 & 0.98 & 0.62 & $\begin{array}{c}\text { Primary } \\
\text { coordination }\end{array}$ \\
\hline 20 & $\begin{array}{c}0.69 \\
\text { lag }\end{array}$ & $\begin{array}{c}0.71 \\
22\end{array}$ & $\begin{array}{c}\text { Touri } \\
\text { sm } \\
\text { lag }\end{array}$ & $\begin{array}{c}0.70 \\
40\end{array}$ & $\begin{array}{c}0.99 \\
99\end{array}$ & $\begin{array}{c}0.83 \\
90\end{array}$ & $\begin{array}{c}\text { Good } \\
\text { coordination }\end{array}$ \\
\hline 20 & 0.96 & 1.00 & $\begin{array}{c}\text { Touri } \\
\text { sm } \\
\text { lag }\end{array}$ & 0.98 & 0.99 & 0.99 & $\begin{array}{c}\text { Quality } \\
\text { coordination }\end{array}$ \\
\hline
\end{tabular}

\subsection{Result Analysis}

\subsubsection{Analysis of comprehensive contribution}

As can be seen from table 3 , the comprehensive contribution of the two systems of tourism and finance in the 2013-2017 years has been increasing year by year, indicating that the two industries have developed well under the background of "the Belt and Road" in 5 years. In 2013 and 2014, the national financial industry lagged behind the tourism industry, while from 2015 to 2017, the national tourism industry lagged behind the financial industry, which is enough to show that the financial industry can provide strong support for the development of tourism.

From the perspective of the comprehensive contribution of tourism, it increased from 0.1539 in 2013 to 0.9644 in 2017, with an upward trend in all years. From the perspective of the comprehensive contribution of the financial industry, the 0.0010 in 2013 increased to 1.0010 in 2017, showing an upward trend in all years. The above reasons are attributed to "the Belt and Road" initiative of China in 2013, which greatly promotes the development of China's tourism and financial industry.

1) Analysis of coupling degree

As can be seen from table 3, since 2013, the coupling degree between the two sectors of tourism and finance in 2013 has been 0.1602 . This is the lowest year since "the Belt and Road" initiative. The coupling degree of the two in 2014-2017 year is $0.9825,0.9888,0.9999$ and 0.9998 , respectively. The coupling degree between the two industries increases year by year. From 2013 to 2017, for the overall distribution of the coupling degree between tourism and financial industry in China, the average value of the coupling degree between tourism and financial industry is 0.8262 , which indicates that the coupling degree of the interaction between the two industries is very strong and the interaction between the elements is very large in the past five years.

\subsubsection{Analysis of coupling coordination degree}

It can be seen from table 3 that from 2013 to 2017, the coordination degree of tourism and financial industry was $0.1114,0.4589,0.6237,0.8390$ and 0.9912 , respectively, with an average value of 0.6048 , showing a rising trend, and the coordination degree level changed from extreme imbalance to high-quality coordination. As can be seen from table 1, from the imbalance stage in 2013-2014 to the coordination stage in 2015-2017, it shows that the coordination degree of China's tourism and financial industry has greatly changed under the initiative of "the Belt and Road", and the development level of the financial industry has been continuously improved, which further promotes the development of the national tourism industry. At the same time, it also shows that the initiative of "the Belt and Road" makes tourism and financial industry continue to develop, and the links and interaction between the two industries are getting stronger and stronger, so that they can promote each other, achieve the coordination and rapid development of the two industries, and finally achieve the high-quality coordination between tourism and financial industry.

\section{Conclusions}

This paper studies the integration degree of Chinese tourism and financial industry under the background of "the Belt and Road". Through the construction of coupling correlation degree model and index system, the empirical analysis of the coupling development level of tourism and finance industries in China from 2013 to 2017 is conducted, and the following conclusions are finally drawn:

(1) From 2013 to 2014, "the Belt and Road" initiative was just put forward, and the development level of China's tourism industry was higher than that of the financial industry (the financial industry lagged behind the tourism industry). From 2015-2017, the development level of China's financial industry was higher than that of the tourism industry (the tourism industry lagged behind the financial industry).

(2) From 2013 to 2017, the coupling degree $\mathrm{C}$ and coupling coordination degree D of China's tourism and financial industry changed in the range of 0.1602-0.9998 and 0.1114-0.9912, respectively. In these five years, the C value kept rising, while the $\mathrm{D}$ value kept floating at a high 
level, and the $\mathrm{C}$ value and $\mathrm{D}$ value were finally close to the highest value 1. It indicates that under the background of "the Belt and Road", China's tourism and financial industry have great demands on each other, and their demands on each other are continuously increasing.

(3) Under the background of "the Belt and Road", China's tourism and financial industry continue to develop, and the links and interactions between the two industries are getting stronger and stronger. The two industries promote each other, realizing the high-quality coordination and rapid development of the two industries, and finally achieving the common progress of tourism and financial industry, and jointly driving the rapid development of China's economy.

\section{References}

1. China's Belt and Road Official Website. Https://www.yidaiyilu.gov.cn/index.htm.

2. Shiming Peng, Xin Wang, Wei Chen. Conception of development mode of tourism new format under the background of "the Belt and Road" initiative [J]. China Business Theory, 2018, 68-71.

3. Thomas.Bieger,Franz Martin Riklin \&Cliristian Lesser. The rationale behind investments in tourism yentures.A LEST, 51st Congress, 2001, (6): 1-43.

4. Vogel L H. Entertainment Industry Economics: A Guide for Financial Analysis [M]. Song Rui, Lin Hong, trans. Beijing:Citic Press, 2003: 7-16.

5. Hawkins E D, Mann S. The World Bank's role in tourism development[J]. Annals of Tourism Research, 2007, 34(2): 348-363.

6. Markandya A, Taylor T, Pedroso S. Tourism and Sustainable Development: Lessons from Recent World Bank Experience [R].Bizkaia: BC3-Basque Centre for Climate Change, 2014: 20-25.

7. Xia Zhu. Mode and legal system guarantee of integrated development of tourism and financial industry [J]. China Economic and Trade Guide, 2013(27) : 42-44.

8. Yan Gong. Integration of tourism and finance: influencing factors, modes and paths [J]. Journal of Yunnan University for Nationalities (Philosophy and Social Sciences Edition),2015, 115-120.

9. Ping Hua. Countermeasures for integrated development of financial industry and tourism in henan province based on grey correlation analysis [J], Financial Theory and Practice, 2015 (5):66-69.

10. Yan Gong, Zhengrong Guo. Empirical analysis on the coupling and coordinated development of tourism and financial industry -- a case study of jiangsu province [J]. Journal of Tourism, 2017, 74-84.

11. Yuzhen Shao. Study on integration degree of tourism and financial industry in zhejiang province - an empirical study based on data from 2001 to 2016[J].Economic Research Guide, 2008,161$163+172$.

12. Zhaoxiang Gin,Wei Zhang.Analysis of influencing factors and paths of integrated development of tourism and financial industry $[\mathrm{J}]$. China Business Theory, 2018,(21),40-41.

13. Yuzhen Shao. Study on the integration of tourism and financial industry in jiangsu, zhejiang and Shanghai [D]. Zhejiang: Zhejiang GongShang University, 2018.

14. Wenjing Zhang. Countermeasures for integrated development of financial industry and tourism in Henan province -- based on grey correlation analysis [J]. Times Finance, 2008, 79+86.

15. Xin Shi. Research on the impact of tourism on financial industry in the context of international tourism island $[\mathrm{J}]$. Rural Economy and Technology, $2008,71+73$.

16. Li Zhang. Research on the coupling development of tourism and finance in xinjiang [D]. Xinjiang: Xinjiang University of Finance and Economics, 2018.

17. Xiaolin Shu, Yingcao Gao,Yuanxia Zhang.Coupling relationship and coordinated development of tourism industry and ecological civilization city $[\mathrm{J}]$. China's Population, Resources and Environment; 25, 2015 (3); 82-90.

18. Dajin $\mathrm{Wu}, \mathrm{Li}$ Cao, Lihua Chen. Principles and applications of coordination [M]. Wuhan: Huazhong University of Science and Technology Press, 1990.

19. Weiguo Wang. Research on the theory and method of coordinated development [M]. Beijing: China Fiscal and Economic Press, 2000.

20. Yan Gong. Empirical analysis on the coupling and coordinated development of tourism and financial industry -- a case study of jiangsu province [J]. Journal of Tourism, 2017 (3).

21. Liao Chongbin.Quantitative judgment and classification system for coordinated development of environment and economy: A case study of the city group in the Pearl River Delta[J]. Tropical Geography, 1999, 19(2): 171-177. 